\title{
Investigation on carbon sequestration capacity of typical subtropical evergreen broad-leaved forest in Wuyi Mountain National Nature Reserve
}

\author{
Qiugen Zhang ${ }^{1 *}$, Hongli Wang ${ }^{1}$, Yuan Ding ${ }^{1}$, and Jian $\mathrm{Li}^{1}$ \\ ${ }^{1}$ School of Environment and Chemistry Engineering, Nanchang HangKong University, 330063, China
}

\begin{abstract}
Three typical substropical evergreen broad-leaved forests (Castanopsis eyrei, Schima superba and Cyclobalanopsis glauca) in Wuyi Mountain National Nature Reserve of Jiangxi Province were selected to investigate its carbon sequestration capacity. The biomass and soil bulk density of sample investigation were get by setting sample investigation, field quadrat sampling, indoor sample making, experimental analysis testing, data statistics and analysis. The organic carbon content of vegetation layer (arbor layer, shrub layer and herbaceous layer, litter layer) and soil layer $(0-10 \mathrm{~cm}, 10-20 \mathrm{~cm}, 20-30 \mathrm{~cm}, 30-50 \mathrm{~cm}$ and $50-100 \mathrm{~cm})$ were also get. The carbon density and carbon storage of subtropical evergreen broad-leaved forests vegetation and soil were estimated which including Castanopsis eyrei, Schima superba and Cyclobalanopsis glauca. The investigation results had shown that:

The average organic carbon content of each vegetation layer in the investigation plot (400 $\left.\mathrm{m}^{2}\right)$ of Wuyi Mountain National Nature Reserve was arbor layer (54.07\%)> shrub layer (52.8\%)> herbaceous layer (47.5\%), in which the average organic carbon content of the three subtropical evergreen broad-leaved forests in the arbor layer was close $52.97 \%$ to $54.87 \%$ and the total average content was $54.07 \%$. The average carbon density of the forest vegetation layer was $178.3587 \mathrm{t} / \mathrm{hm}^{2}$, the average carbon density of the vegetation layer was arbor layer $\left(176.0273 \mathrm{t} / \mathrm{hm}^{2}\right)>\operatorname{shrub}$ layer $\left(1.3043 \mathrm{t} / \mathrm{hm}^{2}\right)>$ litter layer $\left(0.8144 \mathrm{t} / \mathrm{hm}^{2}\right)>$ herbaceous layer $\left(0.2127 \mathrm{t} / \mathrm{hm}^{2}\right)$; the average carbon density of each forest species was Castanopsis eyrei $\left(213.5141 \mathrm{t} / \mathrm{hm}^{2}\right)>$ Schima superba $\left(168.9069 \mathrm{t} / \mathrm{hm}^{2}\right)>$ Cyclobalanopsis glauca $\left(152.6551 \mathrm{t} / \mathrm{hm}^{2}\right)$.

Investigation sample of subtropical evergreen broad-leaved forest $(400 \mathrm{~m})$ in Wuyi Mountain National Nature Reserve, Jiangxi Province ${ }^{2}$ The average soil bulk density of each soil layer $\mathrm{cm} \mathrm{0-100} \mathrm{g/cm} \mathrm{was} \mathrm{0.868-1.816}$ $\mathrm{g} / \mathrm{cm}^{3}$ both soil organic carbon content and soil carbon density decreased with the increase of soil depth. The average organic carbon content of each soil layer was between $3.75 \%$ and $12.48 \%$, and the average soil carbon density was between $62.85 \mathrm{t} / \mathrm{hm}^{2}$ and $146.14 \mathrm{t} / \mathrm{hm}^{2}$. The average total carbon density of the soil in the investigated sample plots was $754.77 \mathrm{t} / \mathrm{hm}^{2}$, of which the average soil carbon density in investigation sample plots in Castanopsis eyrei, Schima superba and Cyclobalanopsis glauca was $911.49 \mathrm{t} / \mathrm{hm}^{2}, 762.56 \mathrm{t} / \mathrm{hm}^{2}$ and $543.22 \mathrm{t} / \mathrm{hm}^{2}$ respectively.

The average carbon storage of the investigation sample plot $\left(400 \mathrm{~m}^{2}\right)$ in Jiangxi Wuyi Mountain National Nature Reserve were Castanopsis eyrei forest (45.0002t) $>$ Cyclobalanopsis glauca forest (36.6087t) $>$ Schima superba forest (28.4850t), the average soil carbon storage(30.1908t) was 4.23 times the average carbon storage $(7.1314 \mathrm{t})$.
\end{abstract}

\section{Introduction}

Forest ecosystem is an important part of global ecosystem and plays an important role in regulating carbon cycle in the world. Forest plants create favorable conditions for the carbon cycle of the largest forest carbon pool on earth through photosynthesis and respiration.

Jiangxi Province locates in the subtropical region and its forest coverage rate is the second in China. The subtropical evergreen broad-leaved forest is the zonal vegetation of Wuyi Mountain National Nature Reserve in Jiangxi Province. The research on carbon storage and carbon density of vegetation and soil in Wuyi Mountain National Nature Reserve in Jiangxi is very rare. Therefore, taking Wuyi Mountain National Nature Reserve of Jiangxi Province as the research area, the carbon sequestration capacity of typical subtropical evergreen broad-leaved forest was studied, which had certain reference value for evaluating the carbon storage of Jiangxi province. It is of great significance to maintain the carbon balance of Jiangxi ecosystem and to curb regional Greenhouse Effect.

\footnotetext{
*Corresponding author:904644628@qq.com
} 


\section{Investigation regional profiles}

Wuyi Mountain National Nature Reserve of Jiangxi Province located in the south edge of Yanshan County. It's coordinates are $27^{\circ} 48^{\prime} 11^{\prime \prime} \sim 28^{\circ} 00^{\prime} 35^{\prime \prime} \mathrm{N}$ and $117^{\circ} 39^{\prime} 30^{\prime \prime} \sim 117^{\circ} 55^{\prime} 47^{\prime \prime} \mathrm{E}$. The total area of the reserve area is $16007 \mathrm{hm}^{2}$, among which the core area is $4835 \mathrm{hm}^{2}$, the buffer area is $2021 \mathrm{hm}^{2}$, and the experimental area is $9151 \mathrm{hm}^{2[1]}$. The main peak Huanggang Mountain is the highest peak in six provinces and one city in east China. The reserve is connected with Fujian Wuyi Mountain National Nature Reserve in the southeast.

Jiangxi Wuyi Mountain National Nature Reserve locates in the subtropical East monsoon humid region, with an average annual temperature of $14.2^{\circ} \mathrm{C}$, average annual precipitation of $2583 \mathrm{~mm}$, average annual sunshine hour of $964 \mathrm{~h}$, average annual evaporation of $778 \mathrm{~mm}$, and average annual relative humidity of $84 \% \%^{[1-2]}$.

The main protected objects of Wuyi Mountain National Nature Reserve in Jiangxi Province are subtropical evergreen broad-leaved forest and its forest ecosystem, with a forest coverage rate of $92.7 \%$. The vegetation types in the reserve are mainly composed of evergreen broad-leaved forest, evergreen broad-leaved mixed forest, coniferous and broad-leaved mixed forest, and coniferous forest, moss dwarf forest on the top of mountain and shrub meadow on the top of mountain. The subtropical evergreen broad-leaved forest is the most important zonal vegetation type in Wuyi Mountain National Nature Reserve in Jiangxi Province ${ }^{[1-2]}$.

\section{Methods of investigation, analysis and calculation}

\subsection{Investigation methods}

Three kinds of subtropical evergreen broad-leaved forest $(20 \mathrm{~m} \times 20 \mathrm{~m})$ were selected in Wuyi Mountain National Nature Reserve of Jiangxi Province. Three shrub plots $(2 \mathrm{~m} \times 2 \mathrm{~m})$ were set up in each investigation plot, and 1 herbaceous quadrat $(1 \mathrm{~m} \times 1 \mathrm{~m})$ and 1 litter quadrat $(1 \mathrm{~m} \times 1 \mathrm{~m})$ were randomly set up in each shrub plot. The biomass of each vegetation layer in the sample land was investigated.

One representative section was selected in each investigation sample, the soil profile $(100 \mathrm{~cm})$ was excavated, and the stratified sampling was carried out with a ring knife $(0-10 \mathrm{~cm}, 10-20 \mathrm{~cm}, 20-30 \mathrm{~cm}, 30-50 \mathrm{~cm}, 50-$ $100 \mathrm{~cm})$. At the same time, soil drill was used to stratified sampling at the center of each shrub sample $(0-10 \mathrm{~cm}, 10-$ $20 \mathrm{~cm}, 20-30 \mathrm{~cm}, 30-50 \mathrm{~cm}, 50-100 \mathrm{~cm}$ ), and each stratified soil was mixed into each stratified soil sample.

\subsection{Analysis methods}

The analysis and detection of sample organic carbon content was completed by Jiangxi Nuclear Industry Environmental Protection Research Center according to the national standard method. The organic carbon content of plant tissue was determined by dry burning method and by element analyzer, and the soil organic carbon content was determined by potassium dichromate oxidationspectrophotometry.

\subsection{Calculation method}

\subsection{Vegetation biomass}

The biomass of each vegetation layer (arbor layer, shrub layer, herbaceous layer, litter layer) was calculated according to formula (1)-(4), respectively.

\subsubsection{Arbor layer biomass}

$$
\operatorname{Ln} B_{(a)}=\left[0.952 \operatorname{Ln}\left(D^{2} H\right)-2.909\right] \times N
$$

Where $B_{(a)}$ refers to the arbor layer biomass $(\mathrm{kg}), D$ is the diameter at breast height of standard wood $(\mathrm{cm}), H$ is the height of standard wood (m) and $N$ is the number of forest trees.

\subsubsection{Shrub biomass}

$$
B_{(s)}=b_{(s)} \times S
$$

Where $B_{(s)}$ refers to shrub biomass $(\mathrm{kg}) ; b_{(s)}$ is shrub biomass per unit area of shrub quadrat $\left(\mathrm{kg} / \mathrm{m}^{2}\right), S$ is the investigation sample area $\left(\mathrm{m}^{2}\right)$.

\subsubsection{Herbaceous biomass}

$$
B_{(h)}=b_{(h)} \times S
$$

Where $B_{(h)}$ refers to the herbaceous layer biomass $(\mathrm{kg})$ of the sample plot; $b_{(h)}$ is the herbaceous biomass per unit area of the herbaceous sample square $\left(\mathrm{kg} / \mathrm{m}^{2}\right)$, and $S$ is the area of the investigation sample plot $\left(\mathrm{m}^{2}\right)$.

\subsubsection{Litter biomass}

$$
B_{(l)}=b_{(l)} \times S
$$

Where $B_{(l)}$ refers to the transposition biomass $(\mathrm{kg}) ; b_{(l)}$ is the amount of falling matter $\left(\mathrm{kg} / \mathrm{m}^{2}\right)$ per unit area of the falling bed sample square, and $\mathrm{S}$ is the area of the investigation sample plot $\left(\mathrm{m}^{2}\right)$.

\subsubsection{Soil bulk density}

The soil bulk density was calculated by formula (5).

$$
P=\frac{M}{V-\frac{m}{\rho}}
$$

Where $P$ refers to the bulk density of soil $\left(\mathrm{g} \cdot \mathrm{cm}^{-3}\right), M$ is the mass ( $\mathrm{g}$ ) after dry and constant weight of soil sample, $V$ is the soil volume $\left(\mathrm{cm}^{3}\right), m$ is the mass $(\mathrm{g})$ of coarse fragment, $\rho$ is the coarse fragment density $\left(\mathrm{g} \cdot \mathrm{cm}^{-3}\right)$.

\subsubsection{Calculation of vegetation carbon storage and carbon density}

The carbon storage and carbon density of vegetation in the investigation sample plot were calculated by formulas (6) and (7) respectively.

$$
C s_{(v)}=B_{(a)} \times C_{(a)}+B_{(s)} \times C_{(s)}+B_{(h)} \times C_{(h)}+B_{(l)} \times C_{(l)}
$$


Where $C s_{(v)}$ refers to carbon storage $(\mathrm{kg})$ of the vegetation layer, $B_{(a)}, B_{(s)}, B_{(h)}, B_{(l)}$ are the biomass $(\mathrm{kg})$ of the arbor layer, shrub layer, herbaceous layer and litter layer, and $C_{(a)}, C_{(s)}, C_{(h)}, C_{(l)}$ are the average organic carbon content of the arbor layer, shrub layer, herbaceous layer and litter layer respectively (\%).

$$
C d_{(v)}=C s_{(v)} / S
$$

Where $C d_{(v)}$ refers to vegetation carbon density $\left(\mathrm{t} \cdot \mathrm{hm}^{-}\right.$ $\left.{ }^{2}\right), C s_{(v)}$ is the vegetation carbon storage $(\mathrm{t})$, and $S$ is the area of the investigation sample $\left(\mathrm{hm}^{2}\right)$.

The carbon density of each vegetation layer can be calculated by removing the carbon storage of each vegetation layer from the sample area.

\subsubsection{Calculation of soil carbon storage and carbon density}

Soil carbon storage and carbon density were calculated by formulas (8), (9) and (10); soil carbon density was multiplied by sample area to obtain soil carbon storage ${ }^{\text {[3- }}$ 5].

The soil carbon density in investigation sample plots was obtained by calculating soil bulk density, organic carbon content and thickness of each soil layer, as formula (8).

$$
C d_{(s i)}=P \times H_{i} \times C_{(s i)}
$$

Where $C d_{(s i)}$ refers to soil carbon density $\left(\mathrm{t} \cdot \mathrm{hm}^{-2}\right)$ in layer i, $P$ is soil bulk density $\left(\mathrm{g} \cdot \mathrm{cm}^{-3}\right), H_{i}$ is soil thickness $(\mathrm{cm})$ in layer $\mathrm{i}$, and $C_{(s i)}$ is soil organic carbon content (\%) in layer $\mathrm{i}$.

$$
C d_{(s)}=\sum_{i=1}^{n} C d_{(s i)}
$$

Where $C d_{(s)}$ refers to soil carbon density $\left(\mathrm{t} \cdot \mathrm{hm}^{-2}\right), C d_{(s i)}$ is the $\mathrm{i}$ layer soil carbon density $\left(\mathrm{t} \cdot \mathrm{hm}^{-2}\right), n=1,2, \ldots 5$.

$$
C s_{(s)}=C d_{(s)} \times S
$$

Where $C s_{(s)}$ refers to the soil carbon storage $(\mathrm{t}), C d_{(s)}$ is the soil carbon density $\left(\mathrm{t} \cdot \mathrm{hm}^{-2}\right)$, and $S$ is the area of the investigation sample $\left(\mathrm{hm}^{2}\right)$.

\section{Investigation results and analysis}

\subsection{Vegetation carbon storage and carbon density}

\subsubsection{Organic carbon content in Vegetation layer}

Through analysis and determination, the average organic carbon content of main organs in arbor layer, shrub layer and herbaceous layer of three subtropical evergreen broadleaved forests in Wuyi Mountain National Nature Reserve of Jiangxi Province was shown in Table 1 to Table 3.

Table 1. Organic carbon content of main organs in arbor layer

\begin{tabular}{cccccc}
\hline Organic carbon content & Leaf (\%) & Branch (\%) & Trunk (\%) & Root (\%) & Arithmetic average (\%) \\
\hline Castanopsis eyrei & 55.73 & 53.77 & 54.2 & 55.77 & 54.87 \\
$\quad$ Schima superba & 56.07 & 52.83 & 52.37 & 50.60 & 52.97 \\
Cyclobalanopsis glauca & 55.47 & 53.27 & 54.1 & 54.67 & 54.38 \\
$\quad$ Average value & 55.76 & 53.29 & 53.56 & 53.68 & 54.07 \\
\hline
\end{tabular}

As can be seen from table 1, the average organic carbon content of three kinds of subtropical evergreen broad-leaved forest in arbor layer was close in the investigation sample plots $\left(400 \mathrm{~m}^{2}\right)$, between $52.97 \sim 54.87 \%$. The comprehensive average content was $54.07 \%$. The average organic carbon content of main organs in arbor layer was leaf $(55.76 \%)>\operatorname{root}>(53.68 \%)>$ trunk $(53.56 \%)$ and branch $(53.29 \%)$. The organic carbon contents of leaves of different forest species were Schima superba $(56.07 \%)>$ Castanopsis eyrei $(55.73 \%)>$ Cyclobalanopsis glauca (55.47\%). The organic carbon content of branch, trunk and root were Castanopsis eyrei $>$ Cyclobalanopsis glauca $>$ Schima superba. The total arithmetic average organic carbon content was Castanopsis eyrei (54.87\%) > Cyclobalanopsis glauca $(54.38 \%)>$ Schima superba $(52.97 \%)$.

Table 2. Organic carbon content of main organs in shrub layer

\begin{tabular}{ccccc}
\hline $\begin{array}{c}\text { Organic carbon } \\
\text { content }\end{array}$ & $\begin{array}{c}\text { Leaf } \\
(\%)\end{array}$ & $\begin{array}{c}\text { Branch } \\
(\%)\end{array}$ & $\begin{array}{c}\text { Root } \\
(\%)\end{array}$ & $\begin{array}{c}\text { Arithmetic } \\
\text { average } \\
(\%)\end{array}$ \\
\hline
\end{tabular}

\begin{tabular}{ccccc}
\hline $\begin{array}{c}\text { Castanopsis } \\
\text { eyrei }\end{array}$ & 55.70 & 54.13 & 54.00 & 54.61 \\
$\begin{array}{c}\text { Schima superba } \\
\text { Cyclobalanopsis }\end{array}$ & 53.00 & 53.70 & 52.17 & 52.96 \\
$\begin{array}{c}\text { glauca } \\
\text { Average value }\end{array}$ & 52.21 & 53.91 & 52.47 & 52.86 \\
\hline
\end{tabular}

As can be seen from table 2, the average organic carbon content of three subtropical evergreen broadleaved forest species of Castanopsis eyrie, Schima superba and Cyclobalanopsis glauca shrub layer in the investigation sample plot $\left(400 \mathrm{~m}^{2}\right)$ ranged from $51.02 \%$ to $54.61 \%$, and the comprehensive average content was $52.86 \%$. The content of organic carbon in the main organs in the sample plot was branch $(53.91 \%)>\operatorname{root}(52.47 \%)>$ leaf $(52.21 \%)$. The content of organic carbon in branch of different forest species was Castanopsis eyrie (54.13\%) > Schima superba $(53.90 \%)>\quad$ Cyclobalanopsis glauca $(53.70 \%)$, and the contents of organic carbon in leaf and root were Castanopsis eyrie > Schima superba > Quercus glauca. The organic carbon content of arithmetic average was Castanopsis eyrie (54.61\%) > 
Cyclobalanopsis glauca (52.96\%) > Cyclobalanopsis glauca $(51.02 \%)$.

Table 3. Organic carbon content of main organs in herbaceous layer

\begin{tabular}{cccc}
\hline $\begin{array}{c}\text { Organic carbon } \\
\text { content }\end{array}$ & Leaf (\%) & Root (\%) & $\begin{array}{c}\text { Arithmetic } \\
\text { average (\%) }\end{array}$ \\
\hline Castanopsis eyrei & 52.55 & 50.6 & 51.58 \\
$\begin{array}{c}\text { Schima superba } \\
\text { Cyclobalanopsis } \\
\text { glauca }\end{array}$ & 49.50 & 47.90 & 48.70 \\
$\begin{array}{c}\text { Average value } \\
\text { Cave.57 }\end{array}$ & 39.54 & 45.47 & 42.24 \\
\hline
\end{tabular}

As can be seen from table 3, the average organic carbon content of the herbaceous layer of three subtropical evergreen broad-leaved forest species of Castanopsis eyrie, Schima superba and Cyclobalanopsis glaucain in the sample plot $\left(400 \mathrm{~m}^{2}\right)$ had some differences, ranging from $42.24 \%$ to $51.58 \%$, and the overall average content was $47.50 \%$. Investigation of organic carbon content in main organs of herbaceous layer in the sample plot was leaf $(49.54 \%)>\operatorname{root}(45.47 \%)$. The average organic carbon content of leaf, root and arithmetic average of different forest species were Castanopsis eyrei (51.58\%)> Schima superba $(48.70 \%)>$ Cyclobalanopsis glauca (42.24\%).

From table 1 to table 3, it can be seen that the average organic carbon content of the investigation sample (400 $\mathrm{m}^{2)}$ in the main organs was arbor layer $(54.07 \%)>$ shrub layer $(52.80 \%)>$ herbaceous layer $(47.50 \%)$.

\subsubsection{Vegetation carbon storage}

The vegetation average carbon storage in investigation sample plot of three typical subtropical evergreen broadleaved forests $\left(400 \mathrm{~m}^{2}\right)$ in Wuyi Mountain National Nature Reserve in Jiangxi Province was shown in Table 4.

Table 4. Vegetation average carbon storage

\begin{tabular}{ccccc}
\hline $\begin{array}{c}\text { Carbon } \\
\text { storage }\end{array}$ & $\begin{array}{c}\text { Castanops } \\
\text { is eyrie } \\
(\mathrm{t})\end{array}$ & $\begin{array}{c}\text { Schim } \\
\text { superb } \\
a \quad(\mathrm{t})\end{array}$ & $\begin{array}{c}\text { Cyclobalanopsi } \\
\text { s glauca }(\mathrm{t})\end{array}$ & $\begin{array}{c}\text { Averag } \\
\mathrm{e}(\mathrm{t})\end{array}$ \\
\hline $\begin{array}{c}\text { Arbor } \\
\text { layer }\end{array}$ & 8.3769 & 6.6778 & 6.0686 & 7.0411 \\
$\begin{array}{c}\text { Shrub } \\
\text { layer }\end{array}$ & 0.0828 & 0.0568 & 0.0169 & 0.0522 \\
$\begin{array}{c}\text { Herbaceous } \\
\text { layer }\end{array}$ & 0.0161 & 0.0028 & 0.0066 & 0.0085 \\
$\begin{array}{c}\text { Litter } \\
\text { layer } \\
\text { Total } \\
\text { storage }\end{array}$ & 0.0648 & 0.0188 & 0.0141 & 0.0326 \\
\hline *arbon storage were calculated by the sample plot area $\left(400 \mathrm{~m}^{2}\right)$
\end{tabular}

As can be seen from table 4, the carbon storage order of different vegetation layers of three typical subtropical evergreen broad-leaved forests of Castanopsis eyrie, Schima superba and Cyclobalanopsis glauca in the investigation plot $\left(400 \mathrm{~m}^{2}\right)$ in Wuyi Mountain National
Nature Reserve in Jiangxi Province was arbor layer $>$ shrub layer $>$ litter layer $>$ herbaceous layer. Among them, the most of the vegetation carbon storage in the investigation plots was concentrated in the arbor layer, accounting for an average of $98.7 \%$. The carbon storage order of arbor layer, shrub layer and litter layer in various forest species in the investigation sample plot was Castanopsis eyrie > Schima superba $>$ Cyclobalanopsis glauca. The carbon storage of herbaceous layer was Castanopsis eyrie > Cyclobalanopsis glauca $>$ Schima superba.

The carbon storage order of the three subtropical evergreen broad-leaved forests of Castanopsis eyrie, Schima superba and Cyclobalanopsis glaucain in the investigation plots in Wuyi Mountain National Nature Reserve in Jiangxi Province was Castanopsis eyrie $(8.5406 \mathrm{t})>$ Schima superba $(6.7563 \mathrm{t})>$ Cyclobalanopsis glauca $(6.1062 \mathrm{t})$. It can be seen that Castanopsis eyrie had played an important role in the carbon balance for Wuyi Mountain forest ecological system.

\subsubsection{Vegetation carbon density}

The average carbon density of different vegetation layers of three typical subtropical evergreen broad-leaved forests $\left(400 \mathrm{~m}^{2}\right)$ in Wuyi Mountain National Nature Reserve in Jiangxi Province was shown in Table 5.

Table 5. Carbon density of different vegetation layers

\begin{tabular}{ccccc}
\hline layer & $\begin{array}{c}\text { Castanopsi } \\
\text { s eyrie } \\
\left(\mathrm{t} / \mathrm{hm}^{2}\right)\end{array}$ & $\begin{array}{c}\text { Schima } \\
\text { superba } \\
\left(\mathrm{t} / \mathrm{hm}^{2}\right)\end{array}$ & $\begin{array}{c}\text { Cyclobalanopsi } \\
\text { s glauca } \\
\left(\mathrm{t} / \mathrm{hm}^{2}\right)\end{array}$ & $\begin{array}{c}\text { Average } \\
\text { density } \\
\left(\mathrm{t} / \mathrm{hm}^{2}\right)\end{array}$ \\
\hline $\begin{array}{c}\text { Arbor } \\
\text { layer }\end{array}$ & 209.4219 & 166.9459 & 151.7141 & 176.0273 \\
$\begin{array}{c}\text { Shrub } \\
\text { layer }\end{array}$ & 2.0700 & 1.4198 & 0.4230 & 1.3043 \\
$\begin{array}{c}\text { Hebaceous } \\
\text { layer }\end{array}$ & 0.4021 & 0.0702 & 0.1657 & 0.2127 \\
$\begin{array}{c}\text { Litter } \\
\text { layer }\end{array}$ & 1.6200 & 0.4710 & 0.3522 & 0.8144 \\
$\begin{array}{c}\text { Total } \\
\text { density }\end{array}$ & 213.5141 & 168.9069 & 152.6551 & 178.3587 \\
\hline
\end{tabular}

According to table 5 , the average carbon density of different vegetation layers in the investigation plot (400 $\mathrm{m}^{2}$ ) of Wuyi Mountain National Nature Reserve in Jiangxi was in the order of arbor layer $\left(176.0273 \mathrm{t} / \mathrm{hm}^{2}\right)>$ shrub layer $\left(1.3043 \mathrm{t} / \mathrm{hm}^{2}\right)>$ litter layer $\left(0.8144 \mathrm{t} / \mathrm{hm}^{2}\right)>$ herbaceous layer $\left(0.2127 \mathrm{t} / \mathrm{hm}^{2}\right)$, which the arbor layer accounted about $98.7 \%$. The average carbon density of the three typical subtropical evergreen broad-leaved forest was in the order of Castanopsis eyrie $\left(213.5141 \mathrm{t} / \mathrm{hm}^{2}\right)>$ Schima superba $\left(168.9069 \mathrm{t} / \mathrm{hm}^{2}\right)>$ Cyclobalanopsis glauca $\left(152.6551 \mathrm{t} / \mathrm{hm}^{2}\right)$, and the overall average carbon density was $178.3587 \mathrm{t} / \mathrm{hm}^{2}$. 


\subsection{Soil carbon storage and carbon density}

\subsubsection{Soil bulk density}

The soil bulk density of three typical subtropical evergreen broad-leaved forests in Wuyi Mountain National Nature Reserve of Jiangxi Province was shown in table 6.

Table 6. Soil bulk density

\begin{tabular}{ccccc}
\hline & \multicolumn{4}{c}{ Soil bulk density $\left(\mathrm{g} / \mathrm{cm}^{3}\right)$} \\
\cline { 2 - 5 } $\begin{array}{c}\text { Depth } \\
(\mathrm{cm})\end{array}$ & $\begin{array}{c}\text { Castanopsis } \\
\text { eyrie }\end{array}$ & $\begin{array}{c}\text { Schima } \\
\text { superba }\end{array}$ & $\begin{array}{c}\text { Cyclobalanopsis } \\
\text { glauca }\end{array}$ & $\begin{array}{c}\text { Average } \\
\text { bulk } \\
\text { density }\end{array}$ \\
\hline $0-10$ & 1.183 & 1.255 & 1.076 & 1.171 \\
$10-20$ & 1.333 & 1.421 & 1.004 & 1.253 \\
$20-30$ & 1.218 & 1.344 & 1.226 & 1.263 \\
$30-50$ & 1.361 & 1.537 & 1.434 & 1.444 \\
$50-100$ & 1.360 & 1.859 & 1.810 & 1.676 \\
\hline
\end{tabular}

As can be seen from table 6, the average soil bulk density of each layer within the range of $0-100 \mathrm{~cm}$ of the investigated sample plot $\left(400 \mathrm{~m}^{2}\right)$ was between $1.171 \mathrm{~g} / \mathrm{cm}^{3}$ to $1.676 \mathrm{~g} / \mathrm{cm}^{3}$, and the average soil bulk density of the 20 $30 \mathrm{~cm}$ soil layer was the largest.

\subsubsection{Soil organic carbon content}

The content of soil organic carbon of three typical subtropical evergreen broad-leaved forests $\left(400 \mathrm{~m}^{2}\right)$ in Wuyi Mountain National Nature Reserve in Jiangxi Province was shown in table 7.

Table 7. Soil organic carbon content

\begin{tabular}{ccccc}
\hline $\begin{array}{c}\text { Soil } \\
\text { depth } \\
(\mathrm{cm})\end{array}$ & $\begin{array}{c}\text { Castanopsis } \\
\text { eyrie }(\%)\end{array}$ & $\begin{array}{c}\text { Schima } \\
\text { superba } \\
(\%)\end{array}$ & $\begin{array}{c}\text { Cyclobalanopsis } \\
\text { glauca }(\%)\end{array}$ & $\begin{array}{c}\text { Average } \\
\text { content } \\
(\%)\end{array}$ \\
\hline $0-10$ & 16.95 & 7.71 & 12.77 & 12.48 \\
$10-$ & 7.69 & 7.1 & 7.55 & 7.45 \\
20 & & & & \\
$20-$ & 7.27 & 4.44 & 5.23 & 5.65 \\
30 & & & & \\
$30-$ & 6.21 & 2.89 & 4.36 & 4.49 \\
50 & & & & \\
$50-$ & 5.16 & 2.12 & 3.98 & 3.75 \\
100 & & & & \\
\hline
\end{tabular}

It can be seen from table 7 that the difference of soil organic carbon content varied with the type of forest vegetation and the depth of the soil layer. The average soil organic carbon content of the investigated sample plot $\left(400 \mathrm{~m}^{2}\right)$ was in the order of Castanopsis eyrie $(5.16 \%)>$ Cyclobalanopsis glauca (3.98\%) > Schima superba $(2.12 \%)$. The average content of soil organic carbon in different soil layers decreased with the increase of soil layer depth. The organic carbon average content in each investigation soil layer of $0-10 \mathrm{~cm}, 10-20 \mathrm{~cm}, 20-30 \mathrm{~cm}, 30-$ $50 \mathrm{~cm}$ and $50-100 \mathrm{~cm}$ was $12.48 \%, 7.45 \%, 5.65 \%, 4.49 \%$ and $3.75 \%$.

\subsubsection{Soil carbon density}

The average soil carbon density of three typical subtropical evergreen broad-leaved forests $\left(400 \mathrm{~m}^{2}\right)$ in Wuyi Mountain National Nature Reserve in Jiangxi Province was shown in table 8 .

Table 8. Soil carbon density

\begin{tabular}{ccccc}
\hline $\begin{array}{c}\text { Depth } \\
\text { of soil } \\
\text { layer } \\
(\mathrm{cm})\end{array}$ & $\begin{array}{c}\text { Castanopsis } \\
\text { eyrie } \\
\left(\mathrm{t} / \mathrm{hm}^{2}\right)\end{array}$ & $\begin{array}{c}\text { Schima } \\
\text { superba } \\
\left(\mathrm{t} / \mathrm{hm}^{2}\right)\end{array}$ & $\begin{array}{c}\text { Cyclobalanopsis } \\
\text { glauca }\left(\mathrm{t} / \mathrm{hm}^{2}\right)\end{array}$ & $\begin{array}{c}\text { Average } \\
\text { carbon } \\
\text { density } \\
\left(\mathrm{t} / \mathrm{hm}^{2}\right)\end{array}$ \\
\hline $0-10$ & 200.52 & 96.76 & 137.41 & 146.14 \\
$10-20$ & 102.51 & 100.89 & 75.80 & 93.35 \\
$20-30$ & 88.55 & 59.67 & 64.12 & 71.36 \\
$30-50$ & 169.04 & 88.84 & 125.04 & 129.67 \\
$50-100$ & 350.88 & 197.05 & 360.19 & 314.25 \\
$\begin{array}{c}\text { Total } \\
\text { density }\end{array}$ & 911.49 & 543.22 & 762.56 & 754.77 \\
\hline
\end{tabular}

It can be seen from table 8 that the soil average carbon density of different depth soil layers in the investigation sample plot $\left(400 \mathrm{~m}^{2}\right)$ generally decreased with the increase of soil depth. The average soil carbon density calculated by $10 \mathrm{~cm}$ of $0-10 \mathrm{~cm}, 10-20 \mathrm{~cm}, 20-30 \mathrm{~cm}, 30-50 \mathrm{~cm}$ and $50-$ $100 \mathrm{~cm}$ was $146.14 \mathrm{t} / \mathrm{hm}^{2}, \quad 93.35 \mathrm{t} / \mathrm{hm}^{2}, \quad 71.36 \mathrm{t} / \mathrm{hm}^{2}$, $64.83 \mathrm{t} / \mathrm{hm}^{2}$ and $62.85 \mathrm{t} / \mathrm{hm}^{2}$, and it changed with the average soil organic carbon content consistently. The average soil carbon density of subtropical evergreen broad-leaved forests in Wuyi Mountain National Nature Reserve in Jiangxi Province was $754.77 \mathrm{t} / \mathrm{hm}^{2}$, and the average soil carbon density of each forest species in descending order was Castanopsis eyrie $\left(911.49 \mathrm{t} / \mathrm{hm}^{2}\right)>$ Cyclobalanopsis glauca $\left(762.56 \mathrm{t} / \mathrm{hm}^{2}\right)>$ Schima superba $\left(543.22 \mathrm{t} / \mathrm{hm}^{2}\right)$. The average carbon density of forest soil in China was $193.55 \mathrm{t} / \mathrm{hm}^{2}{ }^{[6]}$. So it indicated that the carbon density of subtropical evergreen broad-leaved forest in Wuyi Mountain National Nature Reserve in Jiangxi had been higher than the average density of Chinese.

\subsubsection{Soil carbon storage}

The soil carbon storage of three typical subtropical evergreen broad-leaved forests in Wuyi Mountain National Nature Reserve of Jiangxi Province was shown in table 9 .

Table 9. Soil carbon storage

\begin{tabular}{ccccc}
\hline $\begin{array}{c}\text { Depth of } \\
\text { soil } \\
\begin{array}{c}\text { layer } \\
(\mathrm{cm})\end{array}\end{array}$ & $\begin{array}{c}\text { Castanopsis } \\
\text { eyrie }(\mathrm{t})\end{array}$ & $\begin{array}{c}\text { Schima } \\
\text { superba } \\
(\mathrm{t})\end{array}$ & $\begin{array}{c}\text { Cyclobalanopsis } \\
\text { glauca }(\mathrm{t})\end{array}$ & $\begin{array}{c}\text { Average } \\
\text { carbon storage } \\
(\mathrm{t})\end{array}$ \\
\hline $0-10$ & 8.0207 & 3.8704 & 5.4962 & 5.8456 \\
$10-20$ & 4.1003 & 4.0356 & 3.0321 & 3.7339 \\
$20-30$ & 3.5419 & 2.3869 & 2.5648 & 2.8544 \\
$30-50$ & 6.7614 & 3.5535 & 5.0018 & 5.1868 \\
$50-100$ & 14.0352 & 7.8822 & 14.4076 & 12.5700
\end{tabular}


storage

According to table 9, the total average soil carbon storage of the subtropical evergreen broad-leaved forest of investigation sample plot $\left(400 \mathrm{~m}^{2}\right)$ in Wuyi Mountain National Nature Reserve in Jiangxi Province was 30.1908 t. The average soil carbon storage of each forest species was Castanopsis eyrie $(36.4596 \mathrm{t})>$ Cyclobalanopsis glauc $(30.5025 \mathrm{t})>$ Schima superba $(21.7287 \mathrm{t})$, which was consistent with the order of soil carbon density. The average soil carbon storage calculated by $10 \mathrm{~cm}$ of $0-10 \mathrm{~cm}$, $10-20 \mathrm{~cm}, 20-30 \mathrm{~cm}, 30-50 \mathrm{~cm}$ and $50-100 \mathrm{~cm}$ was $5.8456 \mathrm{t}$, $3.7339 \mathrm{t}, 2.8544 \mathrm{t}, 2.5934 \mathrm{t}$ and $2.5140 \mathrm{t}$, which was also consistent with the order of soil organic carbon average content.

\section{Conclusion and discussion}

The vegetation carbon storage and soil carbon storage of three subtropical evergreen broad-leaved forests in Jiangxi Wuyi Mountain National Nature Reserve were summed to obtain the average total carbon storage of the investigation sample plot $\left(400 \mathrm{~m}^{2}\right)$, as shown in table 10 .

Table 10. Forest carbon storage

\begin{tabular}{ccccc}
\hline & $\begin{array}{c}\text { Castanopsis } \\
\text { eyrie }(\mathrm{t})\end{array}$ & $\begin{array}{c}\text { Schima } \\
\text { superba } \\
(\mathrm{t})\end{array}$ & $\begin{array}{c}\text { Cyclobalanops } \\
\text { glauca }(\mathrm{t})\end{array}$ & $\begin{array}{c}\text { Average } \\
\text { carbon } \\
\text { storage }(\mathrm{t})\end{array}$ \\
\hline Vegetation & 8.5406 & 6.7563 & 6.1062 & 7.1343 \\
Soil & 36.4596 & 21.7287 & 30.5025 & 30.1908 \\
Total & 45.0002 & 28.4850 & 36.6087 & 37.3251 \\
\hline
\end{tabular}

It can be seen from table 10 that the average carbon storage in the subtropical evergreen broad-leaved forest of investigation sample plot $\left(400 \mathrm{~m}^{2}\right)$ in Wuyi Mountain National Nature Reserve in Jiangxi was in the order of Castanopsis eyrie $(45.0002 \mathrm{t})>$ Cyclobalanopsis glauca $(36.6087 \mathrm{t})>$ Schima superba $(28.4850 \mathrm{t})$.

The organic carbon content in the arbor layer of the three subtropical evergreen broad-leaved forest species in the investigation sample plot $\left(400 \mathrm{~m}^{2}\right)$ in Wuyi Mountain National Nature Reserve in Jiangxi Province was close, and the content was between $52.97 \%$ and $54.87 \%$. The average carbon density of the vegetation layer was $178.358 \mathrm{t} / \mathrm{hm}^{2}$, and the average carbon density of each vegetation layer from high to low was the arbor layer $\left(176.0273 \mathrm{t} / \mathrm{hm}^{2}\right)>$ the shrub layer $\left(1.3043 \mathrm{t} / \mathrm{hm}^{2}\right)>$ the litter layer $\left(0.8144 \mathrm{t} / \mathrm{hm}^{2}\right)>$ herbaceous layer $\left(0.2127 \mathrm{t} / \mathrm{hm}^{2}\right)$. The average carbon density of each investigated forest species from high to low was Castanopsis eyrie $\left(213.5141 \mathrm{t} / \mathrm{hm}^{2}\right)>$ Schima superba $\left(168.9069 \mathrm{t} / \mathrm{hm}^{2}\right)>$ Cyclobalanopsis glauca $\left(152.6551 \mathrm{t} / \mathrm{hm}^{2}\right)$. The average soil organic carbon content of the subtropical evergreen broad-leaved forest in the sample plot $\left(400 \mathrm{~m}^{2}\right)$ of Wuyi Mountain National Nature Reserve in Jiangxi Province decreased with the increase of soil depth from $12.48 \%$ at $0-10 \mathrm{~cm}$ to $3.75 \%$ at $50-100 \mathrm{~cm}$. The total average forest soil carbon density was
$754.77 \mathrm{t} / \mathrm{hm}^{2}$, and the average soil carbon density of each investigation forest species from high to low was Castanopsis eyrie $\left(911.49 \mathrm{t} / \mathrm{hm}^{2}\right)>$ Cyclobalanopsis glauca $\left(762.56 \mathrm{t} / \mathrm{hm}^{2}\right)>$ Schima superba $\left(543.22 \mathrm{t} / \mathrm{hm}^{2}\right)$.

The total average carbon storage of forest vegetation in the investigation sample plot $\left(400 \mathrm{~m}^{2}\right)$ of Wuyi Mountain National Nature Reserve in Jiangxi Province was $7.1314 \mathrm{t}$, and the total average carbon storage of forest soil was 30.1908t. The carbon storage and the average carbon density of forest soil were 4.23 times as large as that of forest vegetation.

The carbon density and carbon storage of forest vegetation were lower than that of forest soil. The main reason may be that Wuyi Mountain National Nature Reserve in Jiangxi Province had implemented closures for reforestation and forest protection for a long time. The vegetation layer entered the soil system through litter and the vegetation layer participated in the forest. The ecosystem carbon cycle process was relatively short, and the carbon in the vegetation entered the upper layer litter from the litter and entered the soil layer under the action of soil microorganisms while the soil layer participates in the ecosystem carbon cycle process for a longer time. Usually it needs to go through a certain chemical conditions before it can be converted into atmospheric carbon.

\section{Acknowledgments}

This study was financially supported by Key research and development program of Jiangxi province (grant number: 20181ACG70021) and National Natural Science Foundation of China (grant number: 41463005).

\section{References}

1. Jiangxi Wuyi Mountain National Nature Reserve. https://baike.so.com/doc/1697078-1794409.html

2. S.L. Chen, J.S. Liao. Jiangxi Journal of Zoology, 46,66(2011)

3. Seedre M, Kopacek J, Janda P. Forest Ecology and Management, 346,106(2015)

4. Domke G M, Woodall C W, Smith J E. Forest Ecology and Management, 270,108(2012)

5. Manninen S, Zverev V, Bergman I. Science of the Total Environment, 536,616(2015)

6. H.K. Li, Y.C. Lei. Forestry Science, 47, 7(2011) 